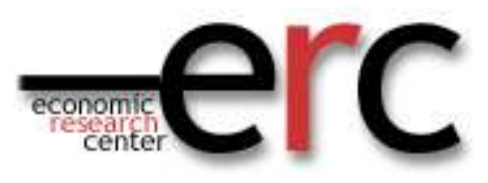

ERC Working Papers in Economics 15/07

August/ 2015

\title{
Resources on the Stage: A Firm Level Analysis of the ICT Adoption in Turkey
}

\author{
Derya Findik
}

Science and Technology Policy Studies Program, Middle East Technical University, Ankara, Turkey

E-mail: dfindik@metu.edu.tr

Phone: + (90) 3122107993

\section{Aysit Tansel}

Department of Economics, Middle East Technical University, Ankara, Turkey and Institute for the Study of Labor (IZA) Bonn, Germany and

Economic Research Forum (ERF) Cairo, Egypt

E-mail: atansel@ metu.edu.tr

Phone: + (90) 3122102073 
Resources on the Stage: A Firm Level Analysis of the ICT Adoption in Turkey $^{1}$

Derya Findik

Science and Technology Policy Studies Program

Middle East Technical University 06800 Ankara, Turkey

E-mail:dfindik@gmail.com

Telephone: 90.312.210 3719

Fax: 90.312. 2107993

and

Aysit Tansel

Cornell University, Ithaca, USA

Middle East Technical University, Ankara, Turkey

E-mail: atansel@metu.edu.tr

Telephone: 90.312.210 2073

Fax: 90.312.210 7964

Institute for the Study of labor (IZA) Bonn, Germany and

Economic Research Forum (ERF) Cairo, Egypt

August, 2014

\begin{abstract}
This study examines the impact of firm resources on ICT adoption by the Turkish business enterprises using firm level data. ICT adoption is measured at three levels: The first level is technology ownership. The second level is the presence of enterprise resource planning (ERP) and customer resource management (CRM), and the third level is the use of narrowband and broadband technologies. The effects of the three main features of each technology level, which are complementarity, specificity, and the complexity, are analyzed by using firm level data in Turkey. This study has three main conclusions. As for the complementarity, firm's resources play an important role in the adoption of technology while advancing from single technology to the multiple ones. Further, in the use of specific technologies such as ERP and CRM, firm resources generate differential effects between those technologies. Finally, the use of simple technologies does not require the same amount of firm resources as complex technologies.
\end{abstract}

Keywords: adoption, ICT, complementarity, specificity, complexity JEL Codes: D22, D24, O30, O47

\footnotetext{
${ }^{1}$ This paper is based on Derya Findik's PhD thesis prepared under the supervision of Prof. Dr. Aysit Tansel at the Science and Technology Policy Studies Program, METU. Derya Findik would like to thank Erkan Erdil and Erol Çakmak for helpful comments on her PhD thesis. Thanks are also due to the staff of the Turkish Statistical Institute for their kind help in implementing this study. They allowed use of the data on their premises. Any errors are our own.
} 


\section{INTRODUCTION}

It is widely acknowledged that technology is a critical determinant of sustainable growth. As an indication of technological progress, the adoption and the use of Information and Communication Technologies (ICTs) are keys to the development of knowledge-based economy and future sustainability. The existence of ICT infrastructure provides business opportunities and helps firms build up business networks between suppliers, buyers and customers. A large number of business tasks are succeeded through the internet by means of personal computers and external network facilities which, in turn, decreases transaction costs. Moreover, use of ICTs provides an efficient channel for advertising, marketing and direct distribution of certain goods and services. ICT plays a dual role, first as part of the technology stock and second as a channel for technology transfer from one organization to another [41].

The aim of this paper is to investigate the impact of firm resources on ICT adoption of Turkish business enterprises. In recent years, telecommunication sector in Turkey witnessed major structural changes. The ongoing changes that started in 2004 led to the abolishment of monopoly rights of the Turkish Telecommunications Authority (TTA). Currently, TTA acts as the main supervisory governing body of the telecommunication sector. Those years also witnessed an increasing trend in the use of ICT components by firms in Turkey. Based on the results of ICT Usage of Enterprises Survey, the use of intranet has increased by 50 percent in between 2007 and 2009. A similar trend is observed in the use of extranet which increased by 65 percent during the same period. In this study, we investigate the mechanisms that leverage the effective use of ICT. We, therefore, focus on the three features of the technology: complementarity, specificity, and complexity. In the adoption literature, complementarity refers that increased adoption of one innovation results in increased adoption of the other. It is commonly used when ICT generates structural changes in the work organization [16, 3]. In that case, the adoption of ICT necessitates the reorganization of the work processes which ultimately affects firm productivity. In our study, we rather analyze the process that shapes the adoption of complementary technologies. The aim is to reveal whether adopting single technology requires the use of same amount of resources as adopting multiple complementary technologies. This carries a strategic importance especially for small firms which have difficulty in baring initial costs of adoption. In most cases, small firms do not make initial software investment required for the adoption of the new technology.

We next elaborate the specificity which refers to the use of technologies that serve specific purposes. We use enterprise resource planning (ERP) and customer resource management (CRM) technologies in this study. While ERP is used to manage firm resources, CRM places the customer at the center of the resource management. Therefore, we assume that each of these technologies requires the exploitation of different types of resources 
at different levels. In this study, we analyze whether firm resources generate differential effects between those specific technologies. We finally discuss the concept of complexity by introducing two types of technologies: narrowband and broadband technologies. We examine whether the adoption of narrowband technologies necessitates the use of similar resources as broadband technologies.

Next we tackle the question of which resources are important for the adoption of ICT. We categorize firm resources based on internal and external characteristics of the organization. Internal characteristics are composed of firm size, human capital, prior knowledge, foreign ownership, openness and purposes of ICT usage. The industry and region within which the firm operates make up the external characteristics. We found that among those resources, the most important effect belongs to human capital for the firms that are heavy users of multiple complementary technologies. This variable is measured by $R \& D$ personnel expenditure per employee which indicates the prominent role of skilled personnel for the technology adoption by Turkish business enterprises. Based on the ICT Usage of Enterprises Survey results, in between 2007 and 2008, the number of firms employing IT experts has increased by 50 percent in Turkey. This may indicate a spillover effect for firms that did not employ IT experts in 2007 but decided on employing IT experts in 2008. For the use of specific technologies, resources generate differential effects. While large and exporting firms are more advantageous for the use of ERP, firms in the services sector rather adopt CRM technology. Additionally, firm resources generate different effects advancing from narrowband technologies to the broadband. Only a few firm resources are necessary for the adoption of narrowband technologies while this is not the case for broadband technologies.

This study contributes to the related literature in at least three ways. First is that this study elaborates the three features of the technology within the ICT adoption framework. Some of the empirical literature focuses on the time of adoption and the adoption intensity [40,46] while some of them deals with the functions of the technology [4, 67, 49]. We assume that each feature corresponds to the different aspects of ICT. As for the adoption of complementary technologies, the most important challenge for firms is to introduce firm resources at an adequate level. Based on our results, firms do not need to use same amount of resources while adopting single technology. Further, firm resources generate different effects between specific technologies. To illustrate, internal characteristics of the firm play a crucial role in the use of ERP, while external characteristics such as being in the service sector eases CRM adoption. Finally, adopting new technologies requires the availability of strategic firm resources, while old technologies do not necessitate this condition. Therefore, moving from simplicity to complexity, firm resources have a strong determining role in technology adoption. The second contribution is that this study focuses on a developing country such as Turkey and tests the effect of resources on ICT adoption, which elicits 
significant results compared to the cases of developed countries [26, 31, 34, $36,54,58]$. Because of data availability issues micro level studies for developing countries are rare. The third contribution is that the empirical analyses in this paper use detailed firm level data, which enables to capture firm heterogeneity.

This paper is organized as follows: Section 2 and 3 briefly discuss the literature on the character of technology and the mechanisms of ICT adoption. The data is explained in section 4 . In section 5 the data used in the empirical application is presented. Section 6 provides a discussion of the results. Concluding remarks appear in Section 7.

\section{THE CHARACTER OF THE TECHNOLOGY}

In this section, we discuss the three features of the technology. These are complementarity, specificity, and complexity. According to our hypothesis, firm resources generate different effects on the technology depending on those features.

\subsection{Complementarity}

Complementarity commonly refers to the situation in which the presence of one component of the system increases the returns of the other. Ashish and Gambardella [5] found positive correlation among complementary activities which serve the same objective. This objective could increase the firm performance at the micro level, while it could lead to a decision between welfare regimes at the macro level.

The complementary type of relation could also be established among the innovation activities. To illustrate, internal R\&D activities have a complementary effect on external R\&D activities $[19,48]$. The former helps building up of absorptive capacity to ease the adoption of the latter. Therefore, the coexistence of these components should support or facilitate knowledge business [52].

Two complementary effects of ICT are mentioned in the literature. The first one is the direct effect which is observed when the capital per worker increases with hardware, telecommunications, and software investment. This process is called as capital deepening. During the period 1995-1998, the direct effect of ICT on average labor productivity became faster than that during the 1990-1995. This is induced by continuous decline in the computer prices and high level of investment, especially in high technology assets and semiconductors [43]. Secondly, the indirect effect indicates changes in business processes with the use of ICT. Accordingly the link between productivity and ICT is re-established through complementary organizational investments [17]. Therefore, the literature on the complementarity of ICT focuses more on the combined effect of ICT and other inputs on the productivity of the firm. In some cases, these inputs could be workplace organization, new products and processes [16,3], human capital [56,38] capabilities [77] and in other cases, external 
environment such as involvement of customers, suppliers, and business partners in the project team [69]. In other words, ICT-productivity link is shaped in the frame of "complementary effect" indicating that ICT creates multiple effects as a single input.

As for the link between adoption and the complementary technologies, the literature rather engages in the time of adoption and the adjustment costs. Jovanovich and Stolyarov [44] take the adjustment costs into account while explaining the adoption of complementary technologies. Their approach emerged as an objection to the view that firms simultaneously increase the quality of their complementary products. They claim that if the adjustment costs of the complementary inputs are not convex, firms may tend to buy the inputs at different times because cheaper inputs have more spare capacity which does not necessitate the replacement for a long time.

In addition to the cost of inputs, heterogeneity among firms determines the differences in the adoption time. In some cases, profit maximizing behavior could make that difference while in the others, prior knowledge and the infrastructure may ease the use of advanced technologies [38]. Further, the presence of skilled workforce can be mentioned as another factor that explains the variation in adoption time. Well educated workers achieve new tasks more efficiently by training. Plant age is also considered to affect adoption. There are two different assumptions on its effect. One assumption is that young plants adopt earlier than old ones and they are more prone to use advanced technologies [8]. On the other hand, the role of experience in the acquisition of ability to use ICT makes old plants adopt faster [11]. However, Dunne [25] found that, plant age is not a determining factor in early adoption. Therefore, both old and young plants use advanced technologies at similar frequencies. As for the firm size, Smith [68] claims that in wholesale and retail sectors, cost savings are greater since large firms adopt complementary technologies earlier than their small counterparts.

In this study, the notion of complementarity is used to construct the technology ownership index. Further, the effect of firm resources on this index is analyzed which is a deviation from the literature that focuses on the effect of complementary technologies. Accordingly, the link between firm resources and the complementary technologies is established as

(H1): Advancing from single technologies to the complementary ones, the effect of firms resources increase.

\subsection{Specificity}

The term specificity is conceived as the presence of components in a system that enables firms to integrate different business functions. In a competitive market; firms are forced to supply services faster and better than their competitors. These goals can be achieved by applying 
information technologies which serve specific purposes. ERP and CRM are two of these technologies which provide impetus to the development of capabilities that are difficult to imitate. ERP is a system which integrates different functions of the firm into a single computer system [60]. Therefore, with the contribution of ERP, enterprises manage resources by using both internal and external information. However, only large firms are able to invest in ERP system due to the high installation costs.

In the context of the customers, the interaction among the relevant customers plays an important role in the development of CRM systems which is built on storing and processing information about the customers [55]. Hence, this interaction triggers a learning process for both sides. Firms that build up organizational skills to serve specific needs of the customers successfully implement new product development processes [37]. Those skills are developed with the help of prior knowledge and the technical staff. In this study, ERP and CRM technologies are selected in order to reveal the effect of the firm resources on these specific technologies. Therefore,

(H2): Firm resources generate differential effects between specific technologies.

\subsection{Complexity: A barrier or an impetus?}

The term complexity is used as one of the components which determine the rate of technology adoption. It reflects the degree to which an innovation is perceived as difficult to understand and use. According to Rogers [64], the less the complexity of the technology, the faster the adoption rate. On the other hand, Tornatzky and Klein [73] argued that there is a positive link between innovation capability and adopting a complex technology. Therefore, less innovative firms are reluctant to bare the adjustment costs of complex technologies. Based on this, firms delay in house adoption of complex technologies until they obtain sufficient technical know-how [6].

In contrast to supplier based perspective, complex technologies could be reduced to a simple form with the user focused perspective [61]. For instance, organizations which develop internal and external linkages are better able to adopt complex technologies. Gallivan [32] mentioned that adopting complex technologies necessitates a high level of coordination among the adopters. We rather analyze the other types of resources such as firm size, foreign ownership, exporting activity, prior knowledge, human capital, regional, and industrial variables. In this study, technologies which are ranked from the narrowband to broadband technologies are analyzed in the frame of complexity. Specifically,

(H3): Adopting complex technologies requires the availability of firm strategic resources, while simple ones do not necessitate this condition. 


\section{MECHANISMS OF ADOPTION DECISION}

There are different mechanisms which affect adoption decision. These mechanisms are much related to the availability of firm resources such as the presence of qualified personnel in the firm. According to the empirical literature, "rank effects" and "epidemic effects" are the dominant factors that explain the adoption of the new technology [18]. In order to elaborate on the effect of firm resources in decision to adopt, we used these different frameworks in this study. Accordingly, rank effect is based on ranking adopters in terms of returns from adoption that are determined by the firm characteristics. To illustrate, large firms adopt the new technology earlier than the smaller ones and the profitability potential arises from the heterogeneity in the adoption time [40]. Additionally, spillover effects from adopters to non-adopters could accelerate the adoption. These effects are covered by epidemic effects.

\subsection{Rank Effect}

In technology adoption research, rank model is mentioned to explain heterogeneity among the firms. Accordingly, returns from the adoption differ based on the adoption time and the intensity [23, 45, 13]. Therefore, firms that adopt the technology when the acquisition costs are below the reservation costs, gain the returns from the early adoption. Rank effects rather focus on firm characteristics that determine the gains from early adoption. These characteristics could be the firm size, firm status, financial resources, the technological knowledge [36] or the qualification and skill structure [15]. In this study we analyzed the characteristics such as the firm size, prior knowledge, openness, and purposes of ICT usage, foreign ownership and human capital.

\subsubsection{Firm size}

Firm size is the most frequently used variable in the adoption studies specifically which use rank or probit models [23]. The relation between firm size and the technology adoption is established based on the costs. If adoption lowers average costs, large firms will have a larger output in comparison to the small firms. Early adoption is, therefore, more profitable for larger firms.

There is a considerable amount of literature which empirically found a positive relation between firm size and ICT adoption [26, 9, 24, 57, 71, 58]. On the other hand, the positive link between ICT adoption and firm size could be blurred in the presence of other factors such as prior knowledge, openness, foreign ownership, purposes of ICT usage, and the human capital. 


\subsubsection{Prior knowledge}

Why do some organizations discover the opportunities of early adoption and not the others? Organizations need prior knowledge to assimilate and use the new one. This process indicates the absorptive capacity of the firm [21]. It shows the firm's capacity for learning, implementing new knowledge, disseminating new knowledge internally, and making use of new sources, and including new technologies. In addition to the firm specific factors such as firm size and input costs, Corrocher \& Fontana [22] found that previously adopted technologies and equipment increase the benefits of ICT adoption.

\subsubsection{Openness}

Openness functionality implies the trade openness of the firm. Whether or not firm operates in the international markets can affect the adoption decision. There could be different motivations for the link between adoption and exporting behavior in that sense. The first one is to access a broad knowledge through external links from which firm learns about the new technology earlier than the others [39].

The second one could be that the content of the business with the international partners may require the adoption of the new technology. To illustrate, if the exported product or service is technology oriented and the exporting relation is continuous, exporting firm is forced to adopt the related technologies to produce and export.

The third one is the international competitive pressure. Accordingly, the presence of competitors in the same sector could enhance the adoption and intensity of use of new technologies [26, 40].

\subsubsection{Purposes of ICT Usage}

The effect of purposes of ICT usage is shaped in the cost-benefit framework. According to this, if a technology promises reduction in the costs or increases the benefits, then adoption of the technology becomes easier. The empirical evidence on the effect of the purposes of ICT has appeared only recently [40, 10, 4]. Hollenstein [38] used the term "objective of ICT usage", and analyzed the effect of quality improvement, cost reduction, and input improvement on adoption. Arvanitis and Hollenstein[4] used the cost reduction, higher flexibility, improving product development, better product quality, securing technological need to explain the motives for the adoption of the advanced manufacturing technologies. Baldwin and Rafiquzzaman[10] mentioned cost-benefit framework to understand the motivation for adopting specific technologies. Therefore, benefits of the technology increases as more information is 
provided through different channels such as suppliers, trade relations, subsidiaries and the university or government laboratories.

E-training and e-banking activities can also be used as purposes of ICT usage. As for the e-training activities, firm may use the internet for the purpose of internal training or job-on the training. This generates two effects. The first is the human capital enhancement. The second is the cost saving. Therefore, firm does not have to allocate a large amount of money to the trainings outside the firm. The similar advantages are also supported by e-banking activities. The use of internet for those activities generates reduction in transaction costs of the firm.

\subsubsection{Foreign Share}

The role of foreign share on ICT adoption is largely studied from an economic development perspective. Under what conditions do foreign owned firms or firms with a relatively high share of foreign capital adopt new technologies earlier than domestic firms? The first motivation is based on the low labor costs. If there are large differences in costs of skilled labor between the two countries, the foreign firms choose to invest in the country with the cheaper labor costs. Accordingly, the presence of foreign capital helps firms learn new skills. However, translating foreign capital investment into domestic skills strongly depends on two main conditions such as the character of the technology and the availability of related infrastructure. Firstly, when the outsourced activities do not necessitate technological expertise, foreign capital does not provide the expected advantage. Secondly, exploitation of benefits from foreign capital is based on the match between the technology and the existing skills of the firm. If the developing country invests in learning the transferred technology through reverse engineering, it attracts more technology transfers from multinationals. Moreover, political environment of the developing country also plays a crucial role in the investment decision of the foreign firms. To illustrate, a tax reduction on foreign capital or relatively low labor costs are the pull factors for multinationals.

Firms that are exporters or have foreign ownership are relatively heavy users of ICT regardless of the size of the firm [63]. Thus, Foreign Direct Investment (FDI) can be powerful channel for the transmission of technology to developing countries by financing new investment, by communicating information about technology to domestic affiliates of foreign firms, and by facilitating the diffusion of technology to local firms. Foreign investors bring both equipment and know-how.

\subsubsection{Human capital}

Barbosa \& Faria [12] analyzed the effect of labor characteristics on the decision to adopt the new technologies. They found that the share of skilled employees has a significant positive impact on the likelihood of new technology adoption. There are different ways of measuring human capital. It can be proxied by education as mentioned in the literature [49, 
40, 26]. Empirical evidence indicates a positive link between capabilities and the adoption evidence [15, 4, 27, 28, 12]. R\&D activities can also be used as an indicator of the capabilities in absorbing new knowledge [20]. In our study; we use R\&D personnel expenditures to indicate both the skill level and the R\&D activities of the firm.

\subsection{Epidemic Effect}

Epidemic model is built on the idea that the speed of usage of a new technology is slow due to the lack of information available about the new technology. Geography and industry are two mechanisms that ease the transmission of tacit knowledge from one organization to another [40].

With the rise of the knowledge based economy, transmission of knowledge among individuals or organizations became less dependent on the geographical location. On the other hand, geographical proximity is still a controversial issue since some regions are more innovative than others. Freeman [29] mentioned "selection environment" to conceive the processes that promote the survival of innovative firms. Selection can occur at various levels such as the level of $R \& D$ project in the $R \& D$ system, the level of the individual within the firm, the level of the firm itself, or the level of the industry or the region. This section examines the literature on the effect of the region and the industry, which are labeled as environmental factors in this study. The main question is through which mechanisms environmental factors could increase the pace of adoption.

\subsubsection{Geographical Proximity}

Geographical proximity is crucial in terms of three components. Firstly, a large part of production is concentrated in small areas. Secondly, firms in the same industry or specialized in similar technological fields are prone to locate in certain places. Finally, this tendency follows sustainable patterns through time [53]. As for the effect of proximity on adoption, some of the literature associates a positive link. This effect is observed more at the initial stages of the adoption [11]. In addition, the learning effect is much stronger at that stage $[11,35,47]$.

Networking effect is one of the mechanisms that make the proximity advantageous for the agents. Tassey [70] proposes that networking is essential for the development of a region's knowledge infrastructure. In addition, Gallaud and Torre [30] emphasize that geographical proximity only influences the innovative performance of firms if there is effective interaction between the agents.

In fact, technology itself has strong network effects meaning that positive feedback from early adopters facilitates potential adopters [66]. Further, region can play an intermediary role in the diffusion of the technology. Firms in the same location tend to connect with each other. This in turn, triggers an imitation process for the latecomers.

\subsubsection{Industry Effects}


The technical capacity of the industry in which the firm operates, also affects the rate of diffusion [65]. Industries could encourage the knowledge flow across firms. For the R\&D intensive industries, the pace of diffusion could be slower since private knowledge sharing is less likely in those industries [2]. Therefore firms in the industries that focus on "basic" research and are "demand driven", are much more prone to share information [75]. Inter-firm mobility in the industry is one of the mechanisms that facilitate knowledge sharing [1].

Figure 1 demonstrates the link between Parts 2 and 3 based on the assumption that mechanisms of adoption decision such as firm size, human capital, openness, foreign spillover, and initial investment, play a great role while advancing from low to high level in the feature of the technology.

\begin{tabular}{|ccc|}
\hline $\begin{array}{l}\text { Complementarity } \\
\text { Low Specificity } \\
\text { Complexity }\end{array}$ & $\begin{array}{c}\text { Size Human Capital Openness Foreign Spillover } \\
\text { High Specificity } \\
\text { Complexity }\end{array}$ \\
\hline
\end{tabular}

Figure 1. Relation between mechanisms and character of the technology

\section{Data}

In this paper, two different databases from Turkish Statistical Institute Database (TURKSTAT) are combined to construct the variables used. These are the Annual Industry and Service Statistics (2007) and the ICT Usage in Enterprises Survey (2009). Firms in the manufacturing and service sectors with more than 10 employees are included in the data. There are 3633 observations in the sample.

Dependent variables are derived from the ICT Usage in Enterprises Survey (2009). Based on the Eurostat ICT Usage Survey Methodology, ICT indicators are separated by Wirthmann [76] into 4 categories. These are: investing in the ICT research, adoption of ICT by businesses, e-commerce, and e-business. In this study, adoption of ICT by businesses and ebusiness activities are used based on the data availability. The first one is measured by technology ownership variable which is composed of complementary technologies such as LAN, wireless LAN, intranet, and extranet while ERP and CRM technologies are in the second group. We use the third category of technologies to include the narrowband and broadband technologies in this study. Narrowband technologies include ISDN. Broadband technologies are composed of ADSL, other fixed connection, and mobile connection.

We used data collected from TURKSTAT. In this study, the determinants of the ICT adoption at firm level are analyzed by using cross section analysis. Cross section analysis is conducted by using the 2009 wave of Use of Information and Communication Technology by Business 
Enterprises Survey and the 2007 wave of Annual Structural Business Statistics Survey.

The Use of Information and Communication Technology by Business Enterprises Survey was first conducted by the TURKSTAT in 2005 based on the methodology developed by Eurostat. The survey includes information on the use of computers, internet and other ICT technologies, and the technological qualification and integration. Specifically, questions are based on the ownership of technologies such as LAN, WLAN, intranet, extranet, website ownership, access to internet, broadband and narrowband connections, e-commerce, e-business, e-government applications, and ICT security.

In 2007, the Address Based Population Registration System (ABPRS) was established aimed at recording all Turkish citizens. There were some differences in the distribution of population by age, sex and regions in the ABPRS when compared to previous censuses. Therefore, new population projections were produced according to the new system. The third wave of the survey which was conducted in 2008 was designed in accordance with the methodology introduced by Eurostat, and was published right after the second wave. The third wave of the survey which was published in 2009 was the revised version of the previous survey and the scope was extended. In this survey, banking, financial leasing and insurance operations of firms were included for the first time. Therefore, the third wave of the survey is used in the cross section estimation of ICT adoption.

As for the data collection methodology, TURKSTAT followed a stratified random sampling which is based on the economic activities and enterprise size. Economic activities are classified in accordance with NACE Rev.2. The sample consists of enterprises with 10 or more people employed. As for the geographical scope, enterprises operating in any region of the country are included in the survey. The target respondent is the director who is in charge of IT-related issues in the firm. For small enterprises, the respondent can be anyone from the managerial unit.

\section{Method}

The technology ownership variable is estimated by the cross section ordered logit model. Dependent variable comes from the Use of Information and Communication Technology by Enterprises Survey (2009) while the explanatory variables belong to the Annual Structural Business Survey(2007). The hypothesis is that firm specific factors have lagged effects on adoption. Responses are based on their own declaration of the subject of the survey so that $\mathrm{y}^{*}$ is the unobserved technology ownership variable. Equation (3) shows that $\mathrm{y}^{*}$ varies in terms of changes in $\mathrm{x}_{\mathrm{i}}$ which is a vector of explanatory variables. $\varepsilon_{\mathrm{i}}$ is an unobserved error term and independent of $\mathrm{x}_{\mathrm{i}}$. The possible outcomes can be arranged as below 


$$
\begin{aligned}
& y^{2}=\{1,2,3,4\} \\
& y^{*}=x_{i} \beta+\varepsilon_{i} \\
& \operatorname{Pr}\left(y_{\mathrm{i}}=\mathrm{m} \mid \mathrm{x}_{\mathrm{i}} \beta, \tau\right)=\mathrm{F}\left(\tau_{\mathrm{m}}-\mathrm{x}_{\mathrm{i}} \beta\right)-\mathrm{F}\left(\tau_{\mathrm{m}-1}-\mathrm{x}_{\mathrm{i}} \beta\right) \\
& \mathrm{y}_{\mathrm{i}}=\left\{\begin{array}{l}
1 \Rightarrow 1 \text { if } \tau_{0}=-\infty \leq \mathrm{y}_{\mathrm{i}}<\tau_{1} \\
2 \Rightarrow 2 \text { if } \tau_{1}=\tau_{1} \leq \mathrm{y}_{\mathrm{i}}<\tau_{2} \\
3 \Rightarrow 3 \text { if } \tau_{2}=\tau_{2} \leq \mathrm{y}_{\mathrm{i}}<\tau_{3}
\end{array}\right.
\end{aligned}
$$

\section{Empirical Specification}

The first dependent variable is the technology ownership. It is assigned integer values from 1 to 4 based on whether the enterprise is equipped with such technologies as Local Area Network (LAN), Wireless LAN, Internal Communication Network (Intranet), and External Communication Network (Extranet) as of January 2009. A Local Area Network (LAN) connects computers and devices within a limited geographical area. Having a LAN connection is referred to as production integrated ICT. It links intra-firm processes to inter-firm operations [49]. Wireless connection is a system in which a large number of computers can connect to a network. Each technology has advantages over the other. LAN provides a faster and more secure connection than WLAN, though the latter is advantageous in that users are able to connect from various locations. An internal communication network (intranet) is used to enhance knowledge sharing within a given firm. It coordinates intra-firm activities and provides a platform on which employees can interact with each other. This type of network not only connects local computers and networks, but other external networks as well, through gateways. Extranet is primarily used for communication between customers and other firms. The ideas behind using intranet and extranet are similar, but differ in terms of the content of network usage. Most extranet knowledge carries codified notions, while the knowledge sharing mechanism of the intranet works within a firm-specific setting.

In the ICT Usage in Enterprises Survey (2009) questionnaire, variables pertaining to technology ownership were asked separately, and an index was constructed out of these variables. This index was prepared on the assumption that the more variety there is in the types of technology used at a firm, the more advanced the level of its technology adoption. For instance, intranet only accommodates a firm's internal communication, while using both intranet and extranet offers a system for managing internal operations on one hand and for coordinating external organization on the other. Hence, it is assumed that the technologies in the index are complementary, and that the presence of both is desirable when available. 
Accordingly, the variable technology ownership takes the value of 1 if the firm uses only one technology. If the firm uses two technologies, the variable takes the value of 2 , and so on until all four technologies are accounted for.

The second group of dependent variables consists of CRM and ERP. To start with, CRM is a system used for collecting information about customers and integrating it into the firm's processes, placing the customer at the center of its activities. In addition, this system introduces internet and software skills in order to coordinate relations with customers. Secondly, the ERP application targets efficient use of firm resources such as labor, machinery and equipment. These two technologies serve specific purposes through integrating different business functions. All variables in this group take the value of 1 if the firms use these technologies and 0 otherwise.

The third group of dependent variables includes connection types such as Integrated Services Digital Network (ISDN), Asymmetric Digital Services Line (ADSL), Other Fixed Connection, and Mobile Connection. Each variable is estimated separately because these technologies are arranged from simple to complex. To illustrate, ADSL is a more advanced technology than ISDN. ISDN is described in the Methodological Manual for Statistics on the Information Society (2009) as a narrowband technology while ADSL is described as a broadband technology. Therefore, using both ADSL and ISDN or another conventional type of connection increases the costs. The reason for incorporating these variables is to reveal whether firms differ in their use of old and new technologies.

Explanatory variables in this study consist of the firm size, human capital, foreign capital, export, purposes of ICT usage, industry, and the region. Firm size, which is widely used in the technology adoption literature, is calculated as the logarithm of the average number of employees. Most studies find that large firms have access to tangible and intangible resources that bring them new opportunities for technological development. The second variable is human capital, measures R\&D personnel expenditure per employee. It is assumed that the presence of R\&D personnel increases the absorptive capacity of the firm and accelerates technology adoption. The third and the forth indicators are export and foreign capital. Firms that export or have foreign ownership are relatively heavy users of ICT regardless of firm size [63]. Foreign capital can be a powerful channel for the transmission of technology to developing countries, financing new investment, communicating information about technology to the domestic affiliates of foreign firms, and facilitating the diffusion of technology to local firms. Foreign investors bring both tangible and intangible capital such as equipment and knowhow. Purposes of ICT usage is another explanatory variable of this group. This variable is measured by e-banking and e-training. E-banking activities include financial activities implemented through the internet, such as online transactions and information gathering from financial 
institutions. In addition, firms may use the internet for educational purposes with the help of e-training applications.

The effect of industry and region dummies is also taken into consideration in this study. Seven industry groups are created based on O'Mahony and Van Ark [62] taxonomy, and are described as a) ICT Producing Manufacturing b) ICT Producing Services c) ICT Using Manufacturing d)ICT Using Services e)Non ICT Manufacturing f)Non ICT Services g)Non ICT Other. However, the number of observations for each category is not representative, thus seven categories are reduced to five. As a consequence, subsectors of each industry are combined regardless of whether ICTs are produced or used. The categories are thus named ICT producing and using manufacturing, ICT producing and using services, non ICT manufacturing, non ICT services, and non ICT other. In this model, the reference category is ICT producing and using manufacturing. This taxonomy, however, is not used with the second and the third group of the dependent variables. In these models, the three main industry groups are manufacturing, construction and services, where construction is the reference category.

Region dummies are also added to the regressions. They consist of six categories constructed using the NUTS definition of the TURKSTAT (2008). From the 12 regions in the NUTS, by combining several regions with a small number of observations, we reduced the number of regions to six. The first region is Istanbul, which includes the 46 percent of the sample. It comprises the reference category.

\section{RESULTS}

This part of the paper discusses the estimation results. Table 1 reports the descriptive statistics of the dependent variables, as well as the correlation matrix. These variables indicate the level of technological advancement of the firms in the sample. From the data it can be inferred that differences among ICT indicators are quite remarkable. We found that 34 percent of the sample is ERP users while 18 percent of the sample uses CRM. On the other hand, the user of ISDN which represents narrowband technology is 20 percent indicating that firms in the sample can be named as "advanced technology users". Based on the correlation matrix, we can see that the correlations between different ICT indicators are quite high. In fact, only ISDN shows a weak relation. The highest correlations are observed among the variables, technology ownership, other fixed connection, and mobile connection.

Table 2 reports the descriptive statistics of the explanatory variables. A great proportion of the firms in the sample use e-banking applications while 43 percent of the sample use internet for e-training applications. It can be inferred that the use of ICT for the multiple purposes which requires using internet for the training purposes as much as e-banking is not at the desired level. As for the other explanatory variables, 10 percent 
of the sample sells their products in the international markets while the share of firms with R\&D personnel expenditure is low.

Table 3 exhibits the results of the technology ownership model. Table 4 shows the marginal effects of a probit model for ERP and CRM. Table 5 gives the marginal effects of a probit model for narrowband and broadband technologies.

The first column on Table 1 shows the full model, which indicates the overall estimation results for ordered logit. In model 1 , the dependent variable reflects "one technology using firm." In model 2, two technologyusing firms are evaluated. Similarly for model three and model four.

In the full model, all coefficients are statistically significant at a 1 percent level of significance except ICT producing and using services, which is significant at a 10 percent level. Non ICT other, Non ICT Manufacturing, and Rest Marmara are not statistically significant.

Firm size provides a positive and significant result for the full model, while its effect is negative and significant in technology models one and two. In models three and four, its effect turns out to be positive and significant. This indicates that being a large firm is positively associated with the ownership of multiple technologies. This result supports the theoretical expectation that establishes a positive link between firm size and adoption based on costs [23] and the empirical evidence that is observed especially in developed countries [26,9, 24, 57, 71, 58].

Signs of export share are positive in the full model but negative in the one and two technology models. However, in the three and four technology models, the effect of export share becomes positive. This result contrasts with some of the previous literature that associates a positive link for the adoption of single technologies such as internet and e-selling [40]. Our result shows that there is a threshold level of technology ownership, at which point the effect of export share becomes positive. Therefore, access to external networks through exporting activities generates benefits for firms which the use the three or four technologies. In addition, exporting firms have the knowledge of more recent technologies which motivate them to adopt multiple complementary technologies.

Negative signs of the export share square indicate that the effect of export share increases at a decreasing rate and declines after a certain point. We observe a similar situation in the case of initial investment. Signs of the initial software investment are positive in the full model and negative in the case of one and two technology ownership models, turning positive in the 3 and 4 technology ownership models. Again there is a threshold level of technology ownership at which initial ICT investment turns positive. These results imply that when one or two technologies are used, large software investment may not be needed. However, when three or four technologies are used, large initial software investment is necessary. This 
result supports the literature that found positive link between prior knowledge and adoption [21, 22].

Although statistically significant, the coefficient estimates for the effect of foreign share ownership are negligible in all models. This may be due to the small number of foreign ownership firms in the data. These results contradict common views in the literature that found positive and significant effect of foreign share on adoption [7, 15, 58, 28].

We next consider the effect of R\&D personnel expenditure per employee on the probability of technology ownership. In the full model, R\&D personnel expenditure per employee increases the probability of technology ownership with a large coefficient estimate. This coefficient estimate is negative in the one and two technology ownership models, but turns positive in the 3 and 4 technology ownership models. This result supports the empirical evidence that found positive effect of capabilities on adoption $[15,4,27,28,12]$. Our results imply that R\&D personnel expenditure per employee reduces the probability of one and two technology ownership but increases the probability of three and four technology ownership. Again indicating a threshold level of technology ownership, we next discuss the effect of various sectors on the probability of technology ownership.

The base sector is ICT producing and using in manufacturing. The ICT producing and using services sector has a positive impact on the probability of technology ownership. In the full model, it is negative, and significant in the one technology model, but insignificant in the two technology ownership model. It is positive and significant in the three and four technology ownership models, where similar patterns are observed in the case of the non ICT services sector. Coefficient estimates are insignificant in the non ICT manufacturing sector and non ICT other sector cases.

For the services sector, regardless of producing, using or not using ICT, the effect on the probability of technology ownership is significant. However, the effects of non ICT manufacturing and non ICT other, or the probability of technology ownership, are insignificant since they are neither using nor producing ICT.

Another explanatory variable, e-banking, refers to the firm's online banking activities. The effect of e-banking on the probability of technology ownership is positive in the full model. It is negative in the one and two technology ownership models, but positive in the three and four technology ownership models. A similar pattern is observed with respect to e-training. These results indicate that use of e-banking and e-training activities requires ownership of more than two technologies. Purposes of ICT usage are determined by various indicators as quality improvement, input improvement, or the cost reduction. Empirical evidence found positive effect of those purposes on adoption $[4,40]$. 
The table also reveals the effect of the regions on the probability of technology ownership, with the base region being Istanbul. The effect of all of regions on the probability of technology ownership relative to Istanbul is negative in the full model. The effect of several regions is positive and statistically significant to the probability of one or two technology ownership models, while the overall results are statistically insignificant.

The effect of various regions is negative and significant to the probability of three and four technology ownership models, while the rest is insignificant. These results indicate that various geographical regions increase the probability of one and two technology ownership relative to Istanbul, while several regions reduce the probability of three and four technology ownership.

The pattern of the signs of the coefficients is negative in the one and two technology ownership models but positive in the three and four technology ownership models. This pattern is valid for export share, initial ICT investment, R\&D personnel expenditure per employee, ICT producing and using services, non-ICT services, e-banking and e-training. This pattern of signs indicates a threshold with regard to these factors at the third and fourth technology ownership level.

Table 4 shows the results for CRM and ERP. Firm size does not exhibit as large a positive effect on CRM users as ERP users. The effect of export share is positive, and having CRM application increases the probability of exporting by 0.30 percent. In addition, firms with foreign capital can use this system despite its small share. R\&D expenditures per employee have a positive effect on the probability of employing CRM. While CRM usage is observed less in the manufacturing industry, its effect is positive and significant. CRM applications are more common in the services industry. Coming to the region dummies, only Aegean, West and Central Anatolia exhibit significant coefficients which are negative for CRM owners in these regions. It shows that CRM is not a relevant application with reference to firm activities in those regions.

ERP systems provide integration of business management processes across different business functions [50]. According to the literature on ERP penetration, firm size matters with reference to the decision to adopt. This does not, however, indicate that this specific technology is unnecessary for small firms. Rather, it implies that implementation costs are higher for them. Therefore, small firms that can afford to acquire ERP systems primarily focus on software investment, while large firms spend more heavily on ERP implementation teams [51]. Large firms, due to resource availability, adopt more quickly. In this study, observations are based on the implementation stage of the technology. Hence, results show system usage rather than investment.

The effect of firm size is greater in comparison with CRM. As for openness to trade, which is measured as the share of exports in total sales of the firm, there is a positive association between it and ERP. We found that the 
performance of non-adopters deteriorates in a competitive marketplace. Attracting foreign direct investment is crucial for adopting ERP systems. Even in the case of high levels of investment on infrastructure, some environmental or governmental factors encourage foreign direct investment. The survey period for this study corresponds with the privatization of the sector, which is expected to trigger competition in the market. Therefore, the positive effect of the foreign share may be due to reforms towards liberalization.

Table 5 shows the results for the narrowband and broadband technologies. As for the narrowband technologies, which are shown by the usage of ISDN, almost all variables exhibited insignificant results and a weak model fit value (McFadden's $R 2=0.01$ ). As for the broadband connections, two types, namely the other fixed connections and the mobile connections, are used in this study. Firm size exhibits a greater and more significant effect for other fixed connections in comparison to the results of narrowband technology usage. Firm size is also significant for mobile connection as GPRS, but its effect is less significant than that of the other fixed connection. This result implies that large firms are more inclined to use the other fixed connection than a mobile connection because it provides a faster connection. The effect of foreign share is larger than the narrow band connection in both the other fixed connection and the mobile connection. E-banking activity has significant and negative effects on narrowband technology, which is consistent with the assumption that ebanking activities require a certain level of technological competence and experience that doesn't exist in narrowband technologies.

\section{CONCLUSION AND POLICY IMPLICATION}

The aim of this paper is to analyze the factors that determine the firms' ICT adoption. Adoption appears in three forms. The first of these is the technology ownership model. For the sake of complementarity, this model incorporates various types of technologies, including LAN, WLAN, intranet and extranet. The idea behind using such an index is that enjoying multiple technologies accommodates a stimulating effect allowing firms to exploit the advantages of their resources. These resources could be specific to the organization such as firm size, foreign ownership, R\&D potential, export share, and purposes of ICT usage. Environmental factors, which include industry and regional characteristics, are external types of resources that affect ICT adoption by the businesses. These resources are assumed to turn into ICT capability and play a crucial role in advancing from single technology to multiple technologies.

The second form of adoption is comprised of CRM and ERP usage. This emphasizes specificity and indicates the presence of technologies that serve specific purposes. For instance, ERP coordinates the management of firm resources by using internal and external information while CRM places the customer at the center of resource management. Firm resources that turn into ICT capability generate differential effects between these 
advanced technologies. Hence, firm resources have a much greater impact on ERP usage, while being in the service sector eases CRM adoption.

The third form of adoption is related to the use of narrowband and broadband technologies, which are ranked from old to new. Narrowband technology is represented by ISDN while other fixed connection and mobile connection represent broadband technologies. The hypothesis is that firms differ in use of old and new technologies. This indicates that differences in resources account for remarkable differences between various forms of adoption. Adopting new technologies requires the availability of firm strategic resources while old technologies do not necessitate this condition. Therefore, in moving from simplicity to complexity, firm resources have a deterministic role in the adoption of technology.

Our contribution to adoption literature is in the way this study deals with the three features of adoption: complementarity, specificity, and complexity. Firms' external and internal resources constitute important channels for each aspect. The other contribution of this study is that it focuses on a developing country and tests the effect of firm resources on ICT adoption, which elicits significant results compared to the cases of developed countries. Analyses are based on firm level data, which is another contribution of this study to the related literature. For a future research, a comparative study with another developing country could be carried out.

As mentioned at the beginning of the paper, developing countries, due to a lack of resources, are inclined towards adopting existing technologies rather than generating new ones. Therefore, it is highly probable that firms that enjoy these resources will adopt earlier and thus pass on the process of creating new technology. The main policy implication could be to find an efficient way of encouraging firms that cannot afford to employ strategic resources and do not have the benefit of being in a key sector or region.

Considering the strategic importance of prior investment, availability of financial resources is necessary, especially for small firms, at the stage at which they begin to operate. Based on the results of our analysis, the effect of initial software investment increases in a model in which multiple technologies are introduced. This implies that prior investment generates incremental effects in the later stages of the adoption.

\section{REFERENCES}

1. Almeida, P. (1996). Knowledge sourcing by foreign multinationals:patent citation analysis in the U.S. semiconductor industry, Strategic Management Journal, 17, 155-265.

2. Appleyard, M.M. (1996). How does knowledge flow? Inter-firm patterns in the semiconductor industry, Strategic Management Journal,17, 137-54. 
3. Arvanitis, S. (2005). Computerization, new workplace organization, skilled labor, and firm productivity: evidence for the Swiss business sector, Economics of Innovation and New Technology, 14, 225-249.

4. Arvanitis, S. \& Hollenstein, H. (2001). The determinants of the adoption of advanced manufacturing technology, Economics of Innovation and New Technology, 10, 377-414.

5. Ashish A.\& Gambardella, A.(1990). Complementarity and external linkages: the strategies of the large firms in biotechnology, The Journal of Industrial Economics, 38, 361-379.

6. Attewell, P. (1992). Technology diffusion and organizational learning: the case of business computing, Organization Science, 3, 1-19.

7. Baldwin, J., Diverty, B., (1995). Advanced Technology Use in Canadian Manufacturing Establishments, Research Paper No. 85. Analytical Studies Branch. Statistics Canada, Ottawa.

8. Baldwin, J. R. \& Sabourin, D. (2002). Impact of the adoption of the advanced information and communication technologies on firm performance in the Canadian manufacturing sector, STI Working Paper 2002/1, OECD, Paris.

9. Baldwin, J.R., Sabourin, D., \&Smith, D. (2004). Firm performance in the Canadian food processing sector: the interaction between ICT, advanced technology use and human resource competencies, The Economic Impact of ICT: Measurement, Evidence and Implications, pp. 153-183, OECD, Paris.

10. Baldwin, R.J.\& Rafiquzzaman, M. (1998). The determinants of the adoption lag for advanced manufacturing technologies, Statistics Canada Working Paper No.117.

11. Baptista, R.(2000). Do innovations diffuse faster within geographical clusters? International Journal of Industrial Organization,18, 515-535.

12.Barbosa, N. \& Faria, A.P. (2008). Technology adoption: does labor skill matter? Evidence from Portuguese firm level data, Empirica,35, 179-194.

13. Battisti, G. \& Iona, A. (2009).The intra-firm diffusion of complementary innovations: evidence from the adoption of management practices by British establishments, Research Policy,38, 1326-1339.

14. Battisti, G. \& Stoneman, P. (2003). Inter firm and intra-firm effects in the diffusion of new process technologies, Research Policy, 1622,1-15.

15. Bosworth, D. (1996). Determinants of the use of advanced technologies, International Journal of the Economics of Business, 383, 269-294. 
16.Bresnahan, T.F., Brynjolfsson, E. \& L.M. Hitt (2002). Information technology, workplace organisation, and the demand for skilled labour: firm-level evidence, Quarterly Journal of Economics, 117, 339-376.

17.Brynjolfsson, E. \& Hitt, L.M. (2000). Beyond computation: information technology, organizational transformation, and business performance, The Journal of Economic Perspectives, 14, 23-48.

18. Canepa, A. \& Stoneman, P. (2003). Financial constraints to innovation in the UK and other European countries: evidence from CIS2 and CIS3, paper presented at the CIS user group conference, Modelling Innovation, DTI Conference Center, London.

19. Cassiman, B. \& Veugelers, R. (2006). In search of complementarity in innovation strategy:internal R\&D and external knowledge acquisition, Management Science,52, 68-82.

20. Cohen, W.M. \& Levinthal, D.A. (1989). Innovation and learning: the two faces of R\&D, The Economic Journal, 99, 569-596.

21. Cohen, W.M. \& Levinthal, D.A. (1990). Absorptive capacity: a new perspective on learning and innovation, Administrative Science Quarterly, 35,128-152.

22. Corrocher, N. \& Fontana, R. (2008). Objectives, obstacles and drivers of ICT adoption: what do IT managers perceive? Information Economics and Policy, 20, 229-242.

23. Davies, S. (1979). The diffusion of process innovations, Cambridge University Press, New York.

24. Delone, W. H. (1981) .Firm size and characteristics of computer use, MIS Quarterly,5, 65-77.

25. Dunne,T. (1994). Plant age and technology use in US manufacturing industries, The RAND Journal of Economics, 25, 488-499.

26.Fabiani, S., Schivardi, F., \& Trento, S. (2005). ICT Adoption in Italian manufacturing: firm Level analysis, Industrial and Corporate Change, 14,1-25.

27. Faria, A., Fenn, P. \& Bruce, A. (2002). Determinants of adoption of flexible production technologies: evidence from Portuguese manufacturing industry, Economics of Innovation and New Technology, 11, 569-580.

28. Faria, A.Fenn, B. \&Bruce, A. (2003). A count data model of technology adoption, The Journal of Technology Transfer, 28,63-79.

29. Freeman, C. (1991). Innovation, changes of techno-economic paradigm, and biological analogies in economics, Revue Economique, 42, 211-232. 
30. Gallaud, D. \&Torre, A. (2005). Geographical proximity and the diffusion of knowledge: the case of SME's in biotechnology, Economics of Science, Technology, and Innovation, 30,127-146.

31. Galliano, D. Roux P, Filippi, M. (2001). Organizational and spatial determinants of ICT adoption: the case of French industrial firms, Environment and Planning A, 33, 9, 1643-1663.

32.Gallivan, J. M. (2001). Organizational adoption and assimilation of complex technological innovations: development and application of a new framework, ACM Sigmis Database, 32,51-85.

33.Geroski, P.A. (2000). Models of technology diffusion, Research Policy, 29, 603-625.

34. Giunta, A. and Trivieri, F. (2007). Understanding the determinants of information technology adoption: Evidence from Italian manufacturing firms, Applied Economics, 39, 10, 1325-1334.

35.Hagerstrand, T. (1967) .The computer and the geographer, Transactions of the Institute of British Geographers, 32, 1-19.

36.Haller, S. A. \& Siedschlag, I. (2011). Determinants of ICT adoption, Applied Economics, 43,3775-3788.

37.Handfield, R. Ragatz, G. Petersen, K. \& Monczka, R. (1999). Involving suppliers in new product development, California Management Review, 42, 59-82.

38.Hempell, T. (2003). Do Computers Call for Training? firm level Evidence on complementarities between ICT and human capital investments, ZEW Discussion Paper No 03-20.

39.Hodgkinson, A. \&McPhee, P. (2002). SME information sourcing for innovation and export market development from local or external networks?, University of Wollongong Working Paper Series02-08.

40.Hollenstein, H. (2004) .Determinants of the adoption of information and communication technologies(ICT): an empirical analysis based on firmlevel data for the Swiss business sector, Structural Change and Economic Dynamics, 15,315-342.

41.Hsieh, C. \& Lin,B. (1998). Internet commerce for small businesses, Industrial Management and Data Systems, 3,113-190.

42.Information Age Initiative(2000). Northern Ireland business in the information age: ICT benchmarking report.

43.Jorgenson, D. W ,Stiroh, K. J. ,Gordon,R.J. \& Sichel, D.E.(2000). Raising the speed limit:U.S: economic growth in the information age, Brookings Papers on Economic Activity, 2000, 125-235. 
44.Jovanovic, B. \& Stolyarov, D. (2000).Optimal adoption of complementary technologies, The American Economic Review, 90, 15-29.

45.Karshenas,M. \& Stoneman, P. (1993). Rank, stock, order, and epidemic effects in the diffusion of new process technologies: an empirical model, RAND Journal of Economics, 24, 503-528.

46.Lal, K. (2005). Determinants of the adoption of e-business technologies, Telematics and Informatics, 22, 181-199.

47.Lindner, R. K. Pardey, P.G., \& Jarrett, F.G.(1982). Distance to information source and the time lag to early adoption to trace element fertilizers, Australian Journal of Agricultural Economics, 26, 98-113.

48.Lokshin, B., Belderbos, R. \& Carree, M. (2008). The Productivity effects of internal and external R\&D: evidence from a dynamic panel data model, Oxford Bulletin of Economics and Statistics, 70, 399-413

49.Luchetti, R. \& Sterlacchini, A. (2004). The Adoption of ICT among SMEs: evidence from Italian survey, Small Business Economics, 23, 151168.

50.Mabert, V.A., Soni, A., \& Venkataraman,M.A. (2000).Enterprise resource planning survey of US manufacturing firms, Production and Inventory Management Journal, 41, 52-58.

51.Mabert, V.A., Soni, A., \& Venkataraman,M.A. (2003).Enterprise resource planning: Managing the implementation process, European Journal of Operational Research, 146, 302-314.

52. Makri, M., Hitt, M. A. \& Lane, P. J. (2010). Complementary technologies, knowledge relatedness, and invention outcomes in high technology mergers and acquisitions, Strategic Management Journal, 31, 602-628.

53. Malmberg, A. (1996). Industrial geography: agglomerations and local milieu, Progress in Human Geography, 25, 392-403.

54. Martins, M. and Oliveira, T. (2007). Determinants of information technology diffusion: a study at the firm level for Portugal, in Remenyi, D. (Ed.). Proceedings of the European Conference on Information Management and Evaluation, Academic Conferences, Reading, MA.

55. Massey,A.,Montoya-Weiss, M. \& Holcomb,K.( 2001).Re-engineering the customer relationship: Leveraging knowledge assets at IBM, Decision Support Systems, 32, 155-170.

56.Milgrom, P. \& Roberts, J.(1990). The economics of modern Manufacturing, The American Economic Review, 80,511-528. 
57. Morgan, A., Colebourne, D. \& Thomas,B. (2006).The development of ICT advisors for SME businesses: an innovative approach, Technovation, 26,980-987.

58.Morionez, A.B. \& Lopez F.L.(2007).A firm level analysis of determinants of ICT Adoption in Spain, Technovation, 27, 352-366.

59.Mouelhi, R.B.A. (2009). Impact of adoption of information and communication technologies on firm efficiency in the Tunisian manufacturing sector, Economic Modelling, 26, 961-967.

60.Nelson, K.\& Somers, M.T. (2001). The impact of critical success factors across the stages of Enterprise Resource Planning Implementations, Proceedings of the $34^{\text {th }}$ Hawaii International Conference on System Sciences.

61.Newell, S., Swann, J.A. \& Galliers, R.D. (2000). A knowledge-focused perspective on the diffusion and adoption of complex information technologies: the BPR example, Information Systems Journal,10, 239-259.

62.O'Mahony, M. \& Ark, B.Y. (2003).EU productivity and competitiveness: an industry perspective: Can Europe resume the catching-up process? Enterprise Publications.

63.Qiang, Z.W.C., Clarke, R.,\& Halewood, N. (2006). The role of ICT in doing business, information and communications for development: global trends and policies, Worldbank, pp.57-147.

64.Rogers, M. E. (2002). Diffusion of preventive innovations, Addictive Behaviors, 27, 989-993.

65.Rosenberg, N. (1972). Factors affecting the diffusion of technology, Explorations in Economic History, 10,3-33.

66. Shapiro, C. (1986). Technology adoption in the presence of network externalities, Journal of Political Economy, 94, 822-841.

67. Shiels, H, Ronan McIvor \& Dolores O'Reilly. (2003). Understanding the implications of ICT adoption: insights from SMEs, Logistics Information Management, 16, 5, 312-326.

68.Smith, M. Y. (2010). A model of the linked adoption of complementary technologies, Economics of Innovation and New Technology, 13, 91-99.

69.Tambe, P. \& Hitt, L. M. (2011). The productivity of information technology investments:new evidence from IT labor data, SSRN eLibrary. 
70.Tassey, G. (1991). The functions of technology infrastructure in a competitive economy, Research Policy,20, 345-361.

71.Teo, S.H.T. \& Tan, M. (1998). An empirical study of adopters and nonadopters of the internet in Singapore, Information \&Management, 34,339345 .

72.Tepav (2007). Türkiye Yatırım Ortamı Değerlendirmesi, (Evaluating Investment Environment in Turkey) Rapor No.41611-TR. Ankara, Turkey.

73.Tornatzky, L.G. \& Klein, K.J. (1982). Innovation characteristics and innovation adoption-implementation: Ameta analysis of findings, IEEE Transactions on Engineering Management, 29, 28-43.

74.TURKSTAT (2008).Indicators of Regional Monitoring, TR31., Ankara Turkey.

75.Von Hippel, E. (1988). The sources of Innovation, Oxford University Press, New York.

76.Wirthmann, A. (2008). Eurostat ICT Usage Surveys, http://ec.europa.eu/eurostat/ict

77.Zhu, K., Kraemer, K. \&Dedrick, J. (2004). Information technology payoff in e-business environments: an international perspective on value creation of e-business in the financial services industry, Journal of Management Information Systems, 21, 17-54. 
Table 1. Descriptive Statistics and Correlations for Dependent Variables

\begin{tabular}{|c|c|c|c|c|c|c|c|c|}
\hline Dependent Variables & Mean & Std. Dev. & $\begin{array}{l}\text { Technology } \\
\text { Ownership }\end{array}$ & ERP & CRM & ISDN & \begin{tabular}{|l|} 
Other \\
Fixed \\
Connection \\
\end{tabular} & $\begin{array}{l}\text { Mobile } \\
\text { Connection }\end{array}$ \\
\hline Technology Ownership & 2.25 & 1.03 & & & & & & \\
\hline ERP & 0.34 & 0.47 & 0.4 & & & & & \\
\hline CRM & 0.18 & 0.38 & 0.3 & 0.34 & & & & \\
\hline ISDN & 0.2 & 0.4 & 0.08 & -0.002 & 0.03 & & & \\
\hline Other Fixed Connection & 0.34 & 0.47 & 0.44 & 0.35 & 0.25 & 0.1 & & \\
\hline Mobile Connection & 0.3 & 0.46 & 0.44 & 0.3 & 0.24 & 0.12 & 0.42 & \\
\hline
\end{tabular}


Table 2. Descriptive Statistics and Correlations for Independent Variables

\begin{tabular}{|c|c|c|c|c|c|c|c|c|c|c|}
\hline $\begin{array}{l}\text { Independent } \\
\text { Variables }\end{array}$ & Mean & $\begin{array}{l}\text { Std. } \\
\text { Dev. }\end{array}$ & $\begin{array}{l}\text { Firm } \\
\text { Size }\end{array}$ & \begin{tabular}{|l} 
Export \\
Share
\end{tabular} & \begin{tabular}{|l} 
Export \\
Share_Square
\end{tabular} & \begin{tabular}{|l} 
Foreign \\
Share
\end{tabular} & $\mid$\begin{tabular}{|l} 
E- \\
Banking
\end{tabular} & $\begin{array}{l}\text { E- } \\
\text { Training }\end{array}$ & $\begin{array}{l}\text { R\&D } \\
\text { Personnel } \\
\text { Expenditure }\end{array}$ & \begin{tabular}{|l} 
Initial \\
software \\
investment \\
per employee
\end{tabular} \\
\hline Firm Size & 5.08 & 1.31 & & & & & & & & \\
\hline Export Share & 0.1 & 0.19 & 0.22 & & & & & & & \\
\hline Export Share_Square & 0.04 & 0.11 & 0.18 & 0.96 & & & & & & \\
\hline Foreign Share & 6.16 & 22.32 & 0.15 & 0.13 & 0.12 & & & & & \\
\hline E-Banking & 0.87 & 0.33 & 0.1 & 0.08 & 0.06 & 0.07 & & & & \\
\hline E-Training & 0.43 & 0.49 & 0.1 & 0.04 & 0.03 & 0.09 & 0.17 & & & \\
\hline $\begin{array}{l}\text { R\&D Personnel Expenditure } \\
\text { per employee }\end{array}$ & .007 & .04 & 0.02 & 0.02 & 0.009 & 0.06 & 0.04 & 0.09 & & \\
\hline $\begin{array}{l}\text { Initial software investment per } \\
\text { employee }\end{array}$ & 1.03 & 2.09 & 0.20 & 0.13 & 0.09 & 0.18 & 0.12 & 0.10 & 0.05 & \\
\hline
\end{tabular}


Table 3.Ologit Estimation Results for Technology Ownership and Marginal Effects for Each Technology Model

\begin{tabular}{|c|c|c|c|c|c|}
\hline Variables & $\begin{array}{l}\text { Technology } \\
\text { Ownership } \\
\text { (Full Model) }\end{array}$ & Model 1 & Model 2 & Model 3 & Model 4 \\
\hline Firm Size & $\begin{array}{l}0.410^{* * *} \\
(0.03)\end{array}$ & $\begin{array}{l}-0.0737 * * * \\
(0.00)\end{array}$ & $\begin{array}{l}-0.0190 * * * \\
(0.00)\end{array}$ & $\begin{array}{l}0.0503^{* * *} \\
(0.00)\end{array}$ & $\begin{array}{l}0.0424^{* * *} \\
(0.00)\end{array}$ \\
\hline Export Share & $\begin{array}{l}1.851^{* * *} \\
(0.61)\end{array}$ & $\left\{\begin{array}{l}-0.332^{* * *} \\
(0.11)\end{array}\right.$ & $\begin{array}{l}-0.0855^{* * *} \\
(0.03)\end{array}$ & $\begin{array}{l}0.227 * * * \\
(0.08)\end{array}$ & $\begin{array}{l}0.191^{* * *} \\
(0.06)\end{array}$ \\
\hline Export Share Square & $\begin{array}{l}-2.800 * * * \\
(1.02)\end{array}$ & $\begin{array}{l}0.502^{* * *} \\
(0.18)\end{array}$ & $\begin{array}{l}0.129 * * * \\
(0.05)\end{array}$ & $\begin{array}{l}-0.343^{* * *} \\
(0.13)\end{array}$ & $\left(\begin{array}{l}-0.289^{* * *} \\
(0.11)\end{array}\right.$ \\
\hline lnitial software investment & $\begin{array}{l}0.128^{* * *} \\
(0.02)\end{array}$ & {$\left[\begin{array}{l}-0.0230 * * * \\
(0.00)\end{array}\right.$} & {$\left[\begin{array}{l}-0.00593 * * * \\
(0.00)\end{array}\right.$} & $\begin{array}{l}0.0157^{* * * *} \\
(0.00)\end{array}$ & $\begin{array}{l}0.0132^{* * * *} \\
(0.00)\end{array}$ \\
\hline Foreign Share & $\begin{array}{l}0.00959 * * * \\
(0.00)\end{array}$ & {$\left[\begin{array}{l}-0.00172^{* * *} \\
(0.00)\end{array}\right.$} & $\begin{array}{l}-0.000443^{* * *} \\
(0.00)\end{array}$ & $\begin{array}{l}0.00117 * * * \\
(0.00)\end{array}$ & $\begin{array}{l}0.000988 * * * \\
(0.00)\end{array}$ \\
\hline $\begin{array}{l}R \& D \text { personnel expenditure } \\
\text { per employee }\end{array}$ & $3.759 * * *$ & $-0.674 * * *$ & $-0.174^{* * *}$ & $0.460 * * *$ & $0.387 * * *$ \\
\hline & $(0.91)$ & $(0.16)$ & $(0.05)$ & $(0.11)$ & $(0.09)$ \\
\hline E-Banking & $\begin{array}{l}0.647^{* * *} \\
(0.10)\end{array}$ & {$\left[\begin{array}{l}-0.130 * * * \\
(0.02)\end{array}\right.$} & $\mid \begin{array}{l}-0.00297 \\
(0.01)\end{array}$ & $\left\{\begin{array}{l}0.0775^{* * *} \\
(0.01)\end{array}\right.$ & $\begin{array}{l}0.0556^{* * *} \\
(0.01)\end{array}$ \\
\hline E-Training & $\begin{array}{l}0.650 * * * \\
(0.06)\end{array}$ & {$\left[\begin{array}{l}-0.114^{* * *} \\
(0.01)\end{array}\right.$} & {$\left[\begin{array}{l}-0.0342^{* * *} \\
(0.01)\end{array}\right.$} & $\begin{array}{l}0.0779 * * * \\
(0.01)\end{array}$ & $\begin{array}{l}0.0699 * * * \\
(0.01)\end{array}$ \\
\hline $\begin{array}{l}\text { ICT Producing and Using } \\
\text { Services }\end{array}$ & $0.184^{*}$ & $-0.0323^{*}$ & -0.00965 & $0.0224^{*}$ & $0.0195^{*}$ \\
\hline & $(0.10)$ & $(0.02)$ & $(0.01)$ & $(0.01)$ & $(0.01)$ \\
\hline Non ICT Services & $\begin{array}{l}0.342^{* * *} \\
(0.11)\end{array}$ & $\begin{array}{l}-0.0578 * * * \\
(0.02)\end{array}$ & $\left\{\begin{array}{l}-0.0216^{* *} \\
(0.01)\end{array}\right.$ & {$\left[\begin{array}{l}0.0411^{* * *} \\
(0.01)\end{array}\right.$} & $\begin{array}{l}0.0383 * * * \\
(0.01)\end{array}$ \\
\hline Non ICT Other & {$\left[\begin{array}{l}-0.0194 \\
(0.14)\end{array}\right.$} & $\begin{array}{l}0.0035 \\
(0.02)\end{array}$ & $\begin{array}{l}0.000871 \\
(0.01)\end{array}$ & {$\left[\begin{array}{l}-0.00238 \\
(0.02)\end{array}\right.$} & $\left(\begin{array}{l}-0.00199 \\
(0.01)\end{array}\right.$ \\
\hline Non ICT Manufacturing & $\begin{array}{l}-0.0371 \\
(0.09)\end{array}$ & $\begin{array}{l}0.00667 \\
(0.02)\end{array}$ & $\begin{array}{l}0.00166 \\
(0.00)\end{array}$ & $\begin{array}{l}-0.00454 \\
(0.01)\end{array}$ & $\begin{array}{l}-0.0038 \\
(0.01)\end{array}$ \\
\hline Rest Marmara & {$\left[\begin{array}{l}-0.0295 \\
(0.10)\end{array}\right.$} & $\begin{array}{l}0.00532 \\
(0.02)\end{array}$ & {$\left[\begin{array}{l}0.00131 \\
(0.00)\end{array}\right.$} & {$\left[\begin{array}{l}-0.00362 \\
(0.01)\end{array}\right.$} & {$\left[\begin{array}{l}-0.00302 \\
(0.01)\end{array}\right.$} \\
\hline Aegean & {$\left[\begin{array}{l}-0.220^{* *} \\
(0.10)\end{array}\right.$} & $\left(\begin{array}{l}0.0411^{* *} \\
(0.02)\end{array}\right.$ & {$\left[\begin{array}{l}0.00707 * * * \\
(0.00)\end{array}\right.$} & $\left\{\begin{array}{l}-0.0269 * * \\
(0.01)\end{array}\right.$ & {$\left[\begin{array}{l}-0.0212^{* *} \\
(0.01)\end{array}\right.$} \\
\hline West and Central Anatolia & $\left\{\begin{array}{l}-0.352^{* * *} \\
(0.10)\end{array}\right.$ & $\begin{array}{l}0.0674^{* * *} \\
(0.02)\end{array}$ & $\begin{array}{l}0.00865 * * * \\
(0.00)\end{array}$ & $\left\{\begin{array}{l}-0.0430 * * * \\
(0.01)\end{array}\right.$ & {$\left[\begin{array}{l}-0.0330 * * * \\
(0.01)\end{array}\right.$} \\
\hline Mediterranean & $\begin{array}{l}-0.635^{* * *} \\
(0.13)\end{array}$ & $\begin{array}{l}0.129 * * * \\
(0.03)\end{array}$ & $\mid \begin{array}{l}-0.000305 \\
(0.01)\end{array}$ & {$\left[\begin{array}{l}-0.0758 * * * \\
(0.01)\end{array}\right.$} & $\begin{array}{l}-0.0532^{* * *} \\
(0.01)\end{array}$ \\
\hline Rest Anatolia & $\begin{array}{l}-0.766^{* * *} \\
(0.14)\end{array}$ & $\begin{array}{l}0.159^{* * *} \\
(0.03)\end{array}$ & {$\left[\begin{array}{l}-0.0075 \\
(0.01)\end{array}\right.$} & $\begin{array}{l}-0.0901 * * * \\
(0.02)\end{array}$ & {$\left[\begin{array}{l}-0.0616 * * * \\
(0.01)\end{array}\right.$} \\
\hline $\begin{array}{l}\text { Cut1 } \\
\text { Constant }\end{array}$ & $\begin{array}{l}1.945^{* * *} \\
(0.17)\end{array}$ & & & & \\
\hline $\begin{array}{l}\text { Cut2 } \\
\text { Constant }\end{array}$ & $\begin{array}{l}3.777 * * * \\
(0.18)\end{array}$ & & & & \\
\hline $\begin{array}{l}\text { Cut3 } \\
\text { Constant }\end{array}$ & $\begin{array}{l}5.155^{* * *} \\
(0.19)\end{array}$ & & & & \\
\hline McFadden's R2 & 0.10 & 0.13 & 0.019 & 0.051 & 0.14 \\
\hline Loglikelihood & -4384.181 & -1861.465 & -2321.744 & -1779.176 & -1347.757 \\
\hline Observations & 3,633 & 3,633 & 3,633 & 3,633 & 3,633 \\
\hline
\end{tabular}

Reference region category is IstanbulReference industry is ICT producing and using manufacturingRobust standard errors in parentheses ${ }^{* * *} p<0.01,{ }^{* *} p<0.05,{ }^{*} p<0.1$ 
Table 4. Marginal Effects for the use of CRM and ERP

\begin{tabular}{|l|l|l|}
\hline VARIABLES & CRM & ERP \\
\hline Firm Size & $0.0313^{* * * *}$ & $0.103^{* * *}$ \\
Export Share & $(0.00)$ & $(0.01)$ \\
Export Share Square & $0.300^{* *}$ & $0.730^{* * *}$ \\
Foreign Share & $(0.12)$ & $(0.16)$ \\
R\&D personnel expenditure per employee & $-0.489^{* *}$ & $-1.018^{* * *}$ \\
E-Banking & $(0.20)$ & $(0.28)$ \\
E-Training & $0.000906^{* * * *}$ & $0.00276^{* * *}$ \\
Manufacturing & $(0.00)$ & $(0.00)$ \\
Services & $0.0120^{* * *}$ & $0.0321^{* * *}$ \\
Rest Marmara & $(0.00)$ & $(0.01)$ \\
West and Central Anatolia & $0.0635^{* * * *}$ & $0.141^{* * *}$ \\
Aegean & $(0.02)$ & $(0.02)$ \\
Mediterranean & $0.111^{* * *}$ & $0.139^{* * *}$ \\
Rest Anatolia & $(0.01)$ & $(0.02)$ \\
McFadden's R2 & $0.0581^{*}$ & $0.188^{* * *}$ \\
Loglikelihood & $(0.03$ & $(0.04)$ \\
Observations & $0.168^{* * *}$ & $0.142^{* * *}$ \\
& $(0.03)$ & $(0.04)$ \\
& 0.03 & $0.130^{* * *}$ \\
& $(0.02)$ & $(0.03)$ \\
& $-0.0763^{* * *}$ & $-0.0924^{* * * *}$ \\
& $(0.02)$ & $(0.02)$ \\
& $-0.0391^{* * *}$ & $-0.0597^{* *}$ \\
& $(0.02)$ & $(0.02)$ \\
& 0.01 & $-0.124^{* * *}$ \\
& $(0.02)$ & $(0.03)$ \\
& 0.00 & $-0.0917^{* * * *}$ \\
& $(0.02)$ & $(0.03)$ \\
& 0.10 & 0.20 \\
& -1.534 .659 & -1.854 .590 \\
& 3633 & 3633 \\
\hline
\end{tabular}

Reference region category is Istanbul

Reference industry is construction

Robust standard errors in parentheses ${ }^{* * *} p<0.01,{ }^{* *} p<0.05,{ }^{*} p<0.1$ 
Table 5.Marginal Effects for Technology Types

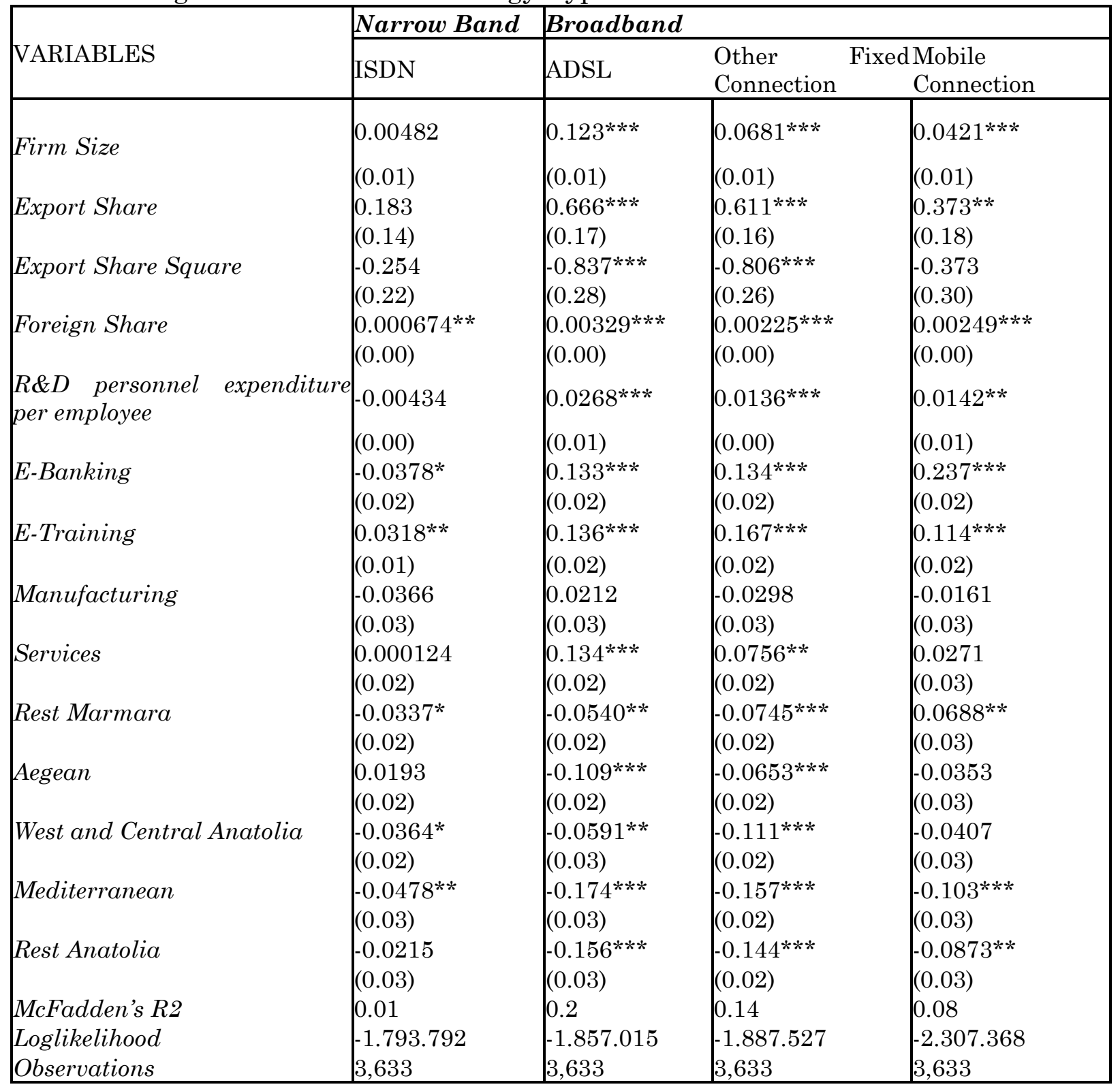

Reference region category is Istanbul

Reference industry is construction

Robust standard errors in parentheses ${ }^{* * *} p<0.01,{ }^{* *} p<0.05,{ }^{*} p<0.1$ 